И. В. Жерносекова, А. А. Тымчук, А. Г. Понизовцева, Н. П. Черногор, А. И. Винников

Днепропетровский национальный университет

\title{
БИОСИНТЕТИЧЕСКИЕ ХАРАКТЕРИСТИКИ МУТАНТНОГО UITAMMA STREPTOMYCES RECIFENSIS VAR. LYTICUS 2P-15 В ПРИСУТСТВИИ ЭКЗОГЕННЫХ АМИНОКИСЛОТ
}

Досліджено дію екзогенних амінокислот на прояв біосинтетичної активності рифампіциностійкого штаму 2Р-15. Показано, що амінокислоти в оптимальних концентраціях (50, 100 , 200 мкг/мл) викликають максимальне збільшення синтезу білка, накопичення біомаси, активності стафілолітичних ферментів і продуктивності стрептоміцету в умовах глибинної ферментації. Усі досліджені амінокислоти забезпечили підвищення стимулювальної активності штаму в 2,0-3,7 раза.

The effect of exogenous amino acids on the biosynthetical activity of rifampycin-resistant strain 2P-15 was studied. Added to the cultivation medium of mutant 2P-15 the optimal concentrations of amino acids $(50,100,200 \mathrm{mcg} / \mathrm{ml})$ increaced a synthesis of protein, biomass, activity of staphylococcus-lytic enzymes and productivity of the strain under conditions of the subsurface fermentation. All investigated amino acids increased the stimulating activity of mutant sfrain $2 \mathrm{P}-15$ by $2.0-3.7$ times.

\section{Введение}

Коммерческое производство продуктов, которые синтезируются микроорганизмами в результате их жизнедеятельности, является приоритетом традиционной биотехнологии. В последнее время существенно расширился список ценных биотехнологических продуктов, с помощью которых преодолеваются продовольственные, энергетические, сырьевые и экологические проблемы. Для создания высококачественного продукта необходимо наличие высокоактивных культур микроорганизмов продуцентов биологически активных веществ, получение которых возможно как традиционными методами селекции, пропластированием, так и методами генетической инженерии $[3 ; 6 ; 14 ; 15]$. Для реализации высокой активности штаммов продуцентов большое значение имеют физико-химические показатели среды, источники питания, экзогенные факторы роста: аминокислоты, пурины, пиримидины, требуемые в малых количествах [15-18]. У многих микроорганизмов потребности в питательных веществах изучены пока недостаточно и их удается культивировать лишь на средах, содержащих сложные природные компоненты, такие как сыворотка крови, жидкость рубца, дрожжевой автолизат или пептоны [4; 16].

Микроорганизмы способны изменять свой обмен в соответствии с изменениями окружающей среды, что открывает возможность для управления их ростом и ферментативной активностью [3; 17]. Применение различных стимуляторов вызывает изменение метаболических процессов у микроорганизмов в сторону увеличения выхода конечного продукта, повышения интенсивности окислительновосстановительных процессов, биосинтеза белка и проницаемости клеточных мембран $[17 ; 20]$. Особого внимания заслуживают стимуляторы химической природыростовые факторы и предшественники синтеза макромолекул, а именно аминокислоты. Внесение гистидина и глутаминовой кислоты в среду культивирования грибов продуцентов пектолитических ферментов вызывает усиление их роста и активизацию синтеза энзимов [1]. Экзогенный метионин усиливает синтез щелочных и нейтральных экзопротеаз у Acremonium chrysogenum [13], лизин - биосинтез цефалоспо-

(C) И. В. Жерносекова, А. А. Тымчук, А. Г. Понизовцева, Н. П. Черногор, А. И. Винников, 2007

Вісник Дніпропетровського університету. Біологія, екологія.

Vìsnik Dnìpropetrovs'kogo unìversitetu. Seriâ Bìologîa, ekologîa Visnyk of Dnipropetrovsk University. Biology, ecology. Vìsn. Dnìpropetr. Unìv. Ser. Bìol. Ekol. 2007. 15(1).

ISSN 2310-0842 print ISSN 2312-301X online www.ecology.dp.ua 
рина $C$ у $C$. aeramonium [26], а также пенициллина у $P$. chrysogenum [25], глутаминовая кислота повышает выход тилозина у $S$. fradiae [21]. Аланин и цистеин усиливают в 1,5-3,0 раза рост и накопление белка в мицелии гриба Fusarium [7]. Ауксинообразование у фото- и гетеротрофных бактерий $[8 ; 10 ; 11]$ также усиливается под воздействием экзогенных аминокислот. Добавление триптофана в концентрациях 50200 мкг/мл в среды выращивания культур Sphingomonas sp. 18, Mycobacterium sp. 1, Rhizobium sp. 5 увеличивает образование ауксина (ИУК) в 28, 30, 34 раза, а к бактериям Rhodococcus sp. 37 и Pseudomonas sp. 24 - в 124 и 103 раза соответственно [19]. Эксперименты in vitro показали, что только некоторые бактериальные культуры могут синтезировать небольшое количество ИУК без добавления экзогенного триптофана, являющегося его метаболическим предшественником [9; 23].

Учитывая то, что аминокислоты служат строительными блоками для образования основных компонентов микробных клеток - белков, а также ферментов, способствуя усилению биосинтетических процессов у многих микроорганизмов, авторы задались целью установить влияние экзогенных аминокислот на проявление биосинтетических свойств мутантного штамма стрептомицета 2P-15.

\section{Материал и методы исследований}

Объект исследования - штамм стрептомицета, устойчивый к рифампицину Streptomyces recifensis var. lyticus 2P-15, синтезирующий комплекс бактериолитических ферментов и стимулятор роста $[6 ; 20]$. Исследования литической активности продуцента проводили с использованием музейного штамма S. aureus 209 Р и стимулирующей активности промышленного штамма C.tropicalis 51. Биосинтетическую активность определяли при глубинном культивировании штамма-продуцента на ферментационной среде на протяжении 72 ч при $+28^{\circ} \mathrm{C}$, в рабочем объеме среды 50 мл и частоте вращения качалки 220 об./мин. [6]. Массу мицелия стрептомицета, отфильтрованного, отмытого $5 \%$ раствором ТХУ и высушенного при $+105^{\circ} \mathrm{C}$ до постоянного веса, определяли весовым методом и выражали в мг/мл. В работе использовали аминокислоты фирмы «Реахим», которые добавляли после стерилизации до конечной концентрации 50, 100, 200 мкг/мл. Стафилолитическую активность определяли турбидиметрическим методом Isono [4] и выражали в ед./мл или ед./мг белка. Белок в пробах определяли методом Bradford [28].

При исследовании ростстимулирующей активности продуцента фильтраты культуральной жидкости (КЖ) предварительно инактивировали автоклавированием. Исследуемые растворы, разведенные 1:10, вносили в стерильную синтетическую среду Ридера из расчета $1 \%$ от объема. Инокулятом служила суточная агаризованная культура дрожжей, приготовленная по стандарту мутности 10 . О ростстимулирующей активности штамма 2P-15 судили по величине прироста биомассы дрожжей в сравнении с контролем. Накопление биомассы дрожжей оценивали оптическим методом на КФК 2 МП при 590 нм в кювете шириной 0,5 см. Стимулирующую активность рассчитывали по формуле, предложенной Черногор [20], и выражали в ед./мл. Все эксперименты проводили в трех повторностях и обрабатывали статистически.

\section{Результаты и их обсуждение}

Синтез белка штаммом 2Р-15 в присутствии треонина увеличился при действии всех исследуемых концентраций, достигнув максимального показателя $156 \%$ к контролю (табл. 1). Показатели синтеза белка при минимальной (50 мкг/мл) и максимальной (200 мкг/мл) концентрации кислоты также превысили контроль, но в меньшей степени, и составили 147 и $139 \%$ соответственно. Очевидно, концентрация треонина

Вісник Дніпропетровського університету. Біологія, екологія.

Vìsnik Dnìpropetrovs'kogo unìversitetu. Serîâ Bìologîa, ekologiâ Visnyk of Dnipropetrovsk University. Biology, ecology. Vìsn. Dnìpropetr. Unìv. Ser. Bìol. Ekol. 2007. 15(1).

ISSN 2310-0842 print ISSN 2312-301X online www.ecology.dp.ua 
100 мкг/мл является оптимальной для стрептомицета, вызывающей самое большое увеличение биосинтеза белка. Из данных литературы известно, что треонин не формирует аминокислотного фонда в микробной клетке, а сразу после проникновения в клетку включается в белок [2]. В присутствии ароматической аминокислоты триптофана биосинтез белка у продуцента стал выше контрольного уровня на 27 \% только при минимальной ее концентрации. Известно, что ароматические аминокислоты полностью в неизменном виде используются микробной клеткой на биосинтетические цели [2].

Биосинтетические характеристики штамма Streptomyces recifensis var. lyticus 2P-15

Таблий 1 в присутствии аминокислот

\begin{tabular}{|c|c|c|c|c|c|c|c|c|c|c|c|c|c|}
\hline \multirow{2}{*}{\multicolumn{2}{|c|}{$\begin{array}{c}\text { Концентрация } \\
\text { аминокислот, } \\
\text { мкг/мл }\end{array}$}} & \multicolumn{2}{|c|}{ Белок } & \multicolumn{2}{|c|}{ Биомасса } & \multicolumn{2}{|c|}{$\begin{array}{l}\text { Литическая } \\
\text { активность }\end{array}$} & \multicolumn{2}{|c|}{$\begin{array}{c}\text { Удельная } \\
\text { активность }\end{array}$} & \multicolumn{2}{|c|}{$\begin{array}{c}\text { Продуктив- } \\
\text { ность }\end{array}$} & \multicolumn{2}{|c|}{$\begin{array}{l}\text { Удельная } \\
\text { скорость } \\
\text { роста, } \mu\end{array}$} \\
\hline & & мг/мЛ & $\begin{array}{c}\% \text { OT } \\
\text { K }\end{array}$ & мг/мл & $\begin{array}{c}\% \text { oT } \\
\text { K }\end{array}$ & ед./мл & \begin{tabular}{|c|}
$\%$ от \\
$\mathrm{K}$ \\
\end{tabular} & ед./мг & $\begin{array}{c}\text { коэфф. } \\
\text { разл. }\end{array}$ & ед./мг & $\begin{array}{c}\% \text { от } \\
\text { K }\end{array}$ & $\mathrm{u}^{-1}$ & $\begin{array}{c}\text { коэфф. } \\
\text { разл. }\end{array}$ \\
\hline \multicolumn{2}{|l|}{ Контроль } & 0,33 & - & $11,5 \pm 0,06$ & - & $2800 \pm 148$ & - & 8485 & - & 243,5 & - & 0,16 & - \\
\hline \multirow{3}{*}{ 兽焉 } & \multirow{3}{*}{$\begin{array}{c}50 \\
100 \\
200\end{array}$} & 0,421 & 127 & $11,6 \pm 0,08^{*}$ & 101 & $4000 \pm 224$ & 143 & 9501 & 1,1 & 344,8 & 141 & 0,16 & 1,0 \\
\hline & & 0,289 & 87 & $11,6 \pm 0,06^{*}$ & 101 & $3733 \pm 96$ & 133 & 12916 & 1,5 & 321,8 & 132 & 0,16 & 1,0 \\
\hline & & 0,296 & 90 & $10,0 \pm 0,10$ & 87 & $2600 \pm 132 *$ & 93 & 8783 & 1,0 & 260,0 & 107 & 0,14 & 0,9 \\
\hline \multirow{3}{*}{ 总 } & \multirow{3}{*}{$\begin{array}{c}50 \\
100 \\
200\end{array}$} & 0,484 & 147 & $10,2 \pm 0,10$ & 89 & $3733 \pm 101$ & 133 & 7713 & 0,9 & 366,0 & 150 & 0,14 & 0,9 \\
\hline & & 0,515 & 156 & $15,0 \pm 0,08$ & 130 & $3733 \pm 98$ & 133 & 7248 & 0,8 & 248,9 & 102 & 0,21 & 1,3 \\
\hline & & 0,460 & 139 & $16,6 \pm 0,12$ & 144 & $3200 \pm 82 *$ & 114 & 6956 & 0,8 & 192,8 & 79 & 0,23 & 1,4 \\
\hline \multirow{3}{*}{ 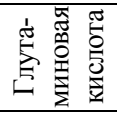 } & \multirow{3}{*}{$\begin{array}{c}50 \\
100 \\
200 \\
\end{array}$} & 0,242 & 73 & $13,2 \pm 0,05$ & 115 & $3466 \pm 86$ & 124 & 14322 & 1,7 & 262,6 & 108 & 0,18 & 1,1 \\
\hline & & 0,234 & 71 & $12,4 \pm 0,08$ & 108 & $3466 \pm 82$ & 124 & 14812 & 2,1 & 279,5 & 115 & 0,17 & 1,1 \\
\hline & & 0,265 & 80 & $24,4 \pm 0,14$ & 212 & $3200 \pm 79 *$ & 114 & 12075 & 1,4 & 131,1 & 54 & 0,34 & 2,1 \\
\hline \multirow{3}{*}{ 䆓志 } & \multirow{3}{*}{$\begin{array}{c}50 \\
100 \\
200\end{array}$} & 0,234 & 71 & $14,2 \pm 0,13$ & 123 & $4533 \pm 183$ & 162 & 19371 & 2,3 & 319,2 & 131 & 0,20 & 1,2 \\
\hline & & 0,289 & 87 & $22,6 \pm 0,10$ & 196 & $3200 \pm 96^{*}$ & 114 & 11073 & 1,3 & 141,6 & 58 & 0,31 & 1,9 \\
\hline & & 0,242 & 73 & $10,8 \pm 0,06$ & 94 & $4000 \pm 160$ & 143 & 16529 & 1,9 & 370,4 & 152 & 0,15 & 0,9 \\
\hline
\end{tabular}

Примечание: * $-p<0,05$.

Присутствие аминокислот (глутаминовой и аргинина) не вызвало увеличения синтеза белка у мутантного штамма 2Р-15 ни в одной из исследуемых концентраций. Их показатели были ниже контрольного уровня и колебались в пределах 71-87\%. Это объясняется тем, что глутаминовая кислота очень быстро образует внутриклеточный пул и только частично расходуется для биосинтеза, а аргинин образует относительно большой пул, который сохраняется в течение длительного промежутка времени без каких бы то ни было изменений [2].

Все исследуемые аминокислоты обеспечили увеличение биомассы штаммом на разных уровнях. Присутствие экзогенного треонина при соответствующих концентрациях (100-200 мкг/мл) способствовало повышению биомассы на 30-44 \%. Это связано с повышением удельной скорости роста - $\mu$ в 1,3 и 1,4 раза по сравнению с контролем. Глутаминовая кислота и аргинин увеличили накопление биомассы штамма до максимального значения 212 и $196 \%$ соответственно, где $\mu$ превысила контроль в 2,1 и 1,9 раза. Аминокислота триптофан не вызывала активного накопления биомассы, так как $\mu$ колебалась в пределах контрольного уровня.

Анализируя активность стафилолитических ферментов, синтезируемых продуцентом, следует отметить, что все исследуемые аминокислоты вызывают повышение активности стафилолизинов в пределах 114-162\%. Максимальный показатель активности выявлен в присутствии аргинина в концентрации 50 мкг/мл, что и обеспечило самый высокий показатель удельной активности на уровне 19371 ед./мг. Известно, что синтез ферментов усиливается в присутствии экзогенных аминокислот, вносимых в питательную среду для культивирования плесневых грибов, вслед-

Вісник Дніпропетровського університету. Біологія, екологія.

Vìsnik Dnìpropetrovs'kogo unìversitetu. Serîâ Bìologîa, ekologiâ Visnyk of Dnipropetrovsk University. Biology, ecology. Vìsn. Dnìpropetr. Unìv. Ser. Bìol. Ekol. 2007. 15(1).

ISSN 2310-0842 print ISSN 2312-301X online www.ecology.dp.ua 
ствие непосредственного включения их в молекулу активного белка. Авторы полагают, что «аминокислоты-стимуляторы» компенсируют недостающие свободные внутриклеточные аминокислоты, необходимые для синтеза фермента [17].

Поскольку в большинстве опытов стабильные биосинтетические характеристики штамма 2Р-15 получены с использованием экзогенного треонина, представляло интерес выяснить возможность замены в среде культивирования продуцента источника азотного питания, а именно соли $\mathrm{NH}_{4} \mathrm{NO}_{3}$ на треонин в концентрации 100 мкг/мл. Из литературы известно, что аминокислоты служат вторыми по значению питательными субстратами после сахаров и являются для бактерий источниками углерода, азота и энергии $[5 ; 16]$. Замена источника азота на треонин привела к снижению всех исследуемых биосинтетических характеристик мутантного штамма 2P-15 (табл. 2, 3).

Таблица 2

Биосинтетические характеристики штамма Streptomyces recifensis var. lyticus $2 \mathrm{P}-15$ при замене источника азотного питания

\begin{tabular}{|c|c|c|c|c|c|c|c|c|c|c|c|c|}
\hline \multirow{2}{*}{$\begin{array}{c}\text { Вариант } \\
\text { опыта }\end{array}$} & \multicolumn{2}{|c|}{ Белок } & \multicolumn{2}{|c|}{ Биомасса } & \multicolumn{2}{|c|}{$\begin{array}{l}\text { Литическая } \\
\text { активность }\end{array}$} & \multicolumn{2}{|c|}{$\begin{array}{c}\text { Удельная } \\
\text { активность }\end{array}$} & \multicolumn{2}{|c|}{$\begin{array}{c}\text { Продуктив- } \\
\text { ность } \\
\end{array}$} & \multicolumn{2}{|r|}{$\mu$} \\
\hline & мг/мл & $\begin{array}{c}\% \text { от } \\
\text { K }\end{array}$ & МГ/MГ & $\begin{array}{c}\% \text { от } \\
\text { K }\end{array}$ & ед./мл & $\% c$ & ед./мг & \begin{tabular}{|c|} 
коэфф. \\
разл.
\end{tabular} & ед./мг & $\%$ от K & $\mathrm{\Psi}^{-1}$ & т К K \\
\hline Контроль & 0,46 & 100 & $9,60 \pm 0,04$ & 100 & $2089 \pm 70,81$ & 100 & 4541 & 1,0 & 217,6 & 100 & 0,13 & 100 \\
\hline Опыт $^{\Delta}$ & 0,104 & 22 & $8,58 \pm 0,03 *$ & 89 & $1044 \pm 34,66 *$ & 50 & 10038 & 2,2 & 122,0 & 56 & 0,12 & 92 \\
\hline
\end{tabular}

Примечание: ${ }^{\Delta}$ - среда с заменой источника азота; ${ }^{*}-p>0,05$.

Таблица 3

Стимулирующая активность штамма Streptomyces recifensis var. lyticus 2P-15 на клетках Candida tropicalis

\begin{tabular}{|c|c|c|c|c|c|c|c|c|c|c|}
\hline \multirow[t]{2}{*}{ Вариант опыта } & \multirow{2}{*}{$\begin{array}{c}\text { Конц. } \\
\text { КЖ, } \\
\%\end{array}$} & \multicolumn{4}{|c|}{ Оптическая плотность, ОД 590 нм } & \multicolumn{2}{|c|}{$\begin{array}{c}\text { Стимули- } \\
\text { рующая } \\
\text { активность }\end{array}$} & \multirow{2}{*}{$\begin{array}{l}\text { Белок } \\
\text { мг/мл }\end{array}$} & \multicolumn{2}{|c|}{$\begin{array}{c}\text { Удельная } \\
\text { стимулирующая } \\
\text { активность }\end{array}$} \\
\hline & & $X \pm m$ & $\begin{array}{c}\% \text { от } \\
\text { K }\end{array}$ & $\Delta \%$ & $\begin{array}{l}\text { контр. } \\
\text { КЖ, \% }\end{array}$ & ед./мл & $\%$ от К & & ед./мг & $\begin{array}{c}\text { коэфф. } \\
\text { различия }\end{array}$ \\
\hline Контроль без КЖ & 0 & $0,17 \pm 0,03$ & 100 & 0 & - & 0 & - & - & - & - \\
\hline КЖ без аминокислот & 1 & $0,30 \pm 0,08^{*}$ & 176 & 76 & 100 & 2530 & 100 & 0,33 & 7666 & 1,0 \\
\hline КЖ + триптофан 50 & 1 & $0,43 \pm 0,10^{*}$ & 253 & 153 & 143 & 5100 & 201 & 0,42 & 12143 & 1,6 \\
\hline КЖ + треонин 100 & 1 & $0,46 \pm 0,05$ & 270 & 170 & 153 & 5670 & 224 & 0,52 & 10904 & 1,4 \\
\hline $\begin{array}{l}\text { КЖ + глутаминовая } \\
\text { кислота } 100\end{array}$ & 1 & $0,39 \pm 0,05$ & 229 & 129 & 130 & 4300 & 170 & 0,23 & 18696 & 2,4 \\
\hline КЖ + агринин 100 & 1 & $0,65 \pm 0,03$ & 382 & 282 & 217 & 9400 & 371 & 0,29 & 32414 & 4,2 \\
\hline
\end{tabular}

Примечание: * $-p<0,05$.

Уровень белка был снижен на 78 \%, накопление биомассы стрептомицетом не превышало контрольного уровня и достигло лишь 89 \%, активность стафилолитических ферментов, лизирующих клетки стафилококка, уменьшилась в два раза. Наблюдалось также снижение продуктивности штамма на $44 \%$ на фоне уменьшения удельной скорости роста клеток стрептомицета на $8 \%$.

Таким образом, замена источника азотного питания $\left(\mathrm{NH}_{4} \mathrm{NO}_{3}\right)$ аминокислотой треонином нецелесообразна, так как среда оказалась несбалансированной по азотному питанию. Подобное изменение Дебабов [3] объясняет задержкой роста при переносе клеток из полноценной среды на минимальную, когда одновременно с замедлением скорости роста наблюдается резкое уменьшение синтеза стабильных типов РНК (рРНК и тРНК), при этом не возрастает активность ряда ферментов (триптофансинтетазы, гомосериндегидрогеназы, треаниндезаминазы) и биосинтеза аминокислот.

Вісник Дніпропетровського університету. Біологія, екологія.

Vìsnik Dnìpropetrovs'kogo unìversitetu. Serìa Bìologiâ, ekologîâ Visnyk of Dnipropetrovsk University. Biology, ecology. Vìsn. Dnìpropetr. Unìv. Ser. Bìol. Ekol. 2007. 15(1).

ISSN 2310-0842 print ISSN 2312-301X online www.ecology.dp.ua 
При исследовании стимулирующей активности штамма 2P-15 на клетках Candida tropicalis, получено увеличение оптической плотности (ОД) клеток дрожжей при внесении КЖ в концентрации $1 \%$. Максимальный прирост биомассы дрожжей в присутствии аргинина составил $282 \%$ (табл. 3).

Уровень стимулирующей активности продуцента в контроле (КЖ без аминокислоты) достиг 2530 ед./мл, в присутствии экзогенного триптофана - 5100, треонина - 5670, глутаминовой кислоты - 4300, аргинина - 9400 ед./мл. В 1,4-4,2 раза по сравнению с контролем увеличилась также удельная стимулирующая активность.

\section{Заключение}

Внесение экзогенных аминокислот в среду выращивания штамма Streptomyces recifensis var. lyticus 2P-15 положительно повлияло на биосинтетическую активность продуцента. При внесении треонина активно увеличился синтез белка (на $56 \%$ ), в присутствии глутаминовой кислоты - выход биомассы стрептомицета (на 112\%), при добавлении аргинина - активность стафилолизинов (на 62\%), в присутствии треонина и аргинина - продуктивность штамма (на 50-52 \%). Внесение триптофана повысило стимулирующую активность продуцента в два раза, треонина - в 2,2 раза, глутаминовой кислоты - в 1,7 раза, аргинина - в 3,7 раза.

\section{Библиографические ссылки}

1. Астапович Н. И. Нуклеотидный фонд и метаболизм микробной клетки. - Минск, 1979. - 150 с.

2. Гершанович В. Н. Транспорт аминокислот, полипептидов и органических кислот у бактерий. - М.: Медицина, 1977. - 184 с.

3. Дебабов В. Г. Современные методы создания промышленных штаммов микроорганизмов / В. Г. Дебабов, В. А. Лившиц // Биотехнология. - М.: Высшая школа, 1988. - Т. 2. - 208 с.

4. Джавец Э. Руководство по медицинской микробиологии / Э. Джавец, Д. А. Мельник, Э. А. Эйдельберг. - М.: Медицина, 1982. - Т. 1. - 368 с.

5. Елинов Н. П. Химическая микробиология. - М.: Высшая школа, 1989. - 448 с.

6. Жерносекова И. В. Изменчивость продуцента литических ферментов Streptomyces recifensis var. lyticus и его селекция. Дис. ... канд. биол. наук. - К., 2002. - 150 с.

7. Закордонец Л. А. Влияние аланина и цистеина на образование биологически активных веществ Fusarium sp. / Л. А. Закордонец, С. М. Супрун // Микробиол. журн. - 1983. T. 45, № 1. - C. 39-43.

8. Иванова Е. Г. Аэробные метилобактерии синтезируют ауксины / Е. Г. Иванова, Н. В. Доронина, Ю. А. Троценко // Микробиология. - 2001. - Т. 70, № 4. - С. 452-458.

9. Кравченко Л. В. Роль корневых экзометаболитов в интеграции макроорганизма с растениями. Автореф. дис. ... д-ра биол. наук. - М., 2000. - 51 с.

10. Мишке И. В. Микробные фитогормоны в растениеводстве. - Рига: Зинатне, 1988. - 151 с.

11. Синтез фитогормона индол-3-уксусной кислоты ризосферными бактериями рода Pseudomonas / Е. А. Мордухова, Н. П. Скворцова, В. В. Кочетков и др. // Микробиология. 1991. - Т. 60, № 3. - С. 494-500.

12. Синтез индолилуксусной кислоты сапрофитной ассоциативной бактерией Agrobacterium radiobacter / Е. М. Муронец, Н. В. Белавина, Т. Н. Митронова, С. В. Каменева // Микробиология. - 1997. - Т. 66, № 4. - С. 506-513.

13. Новак М. И. Регуляция биосинтеза цефалоспорина $C$ у штаммов Acremonium chrysogenum // Проблемы изыскания и биотехнологии новых антибиотиков. - Пущино, 1982. - С. 23.

14. Прист Ф. Внеклеточные ферменты микроорганизмов. - М.: Мир, 1987. - 117 с.

15. Промышленная микробиология / Под ред. Н. С. Егорова. - М.: Высшая школа, 1989. - 688 с.

16. Современная микробиология. Прокариоты / Под ред. Й. Ленгелера. - М.: Мир, 2005. T. $1 .-656 \mathrm{c}$.

17. Стимуляция жизнедеятельности микроорганизмов и вирусов / Под ред. М. Х. Шигаевой. - Алма-Ата, Наука, 1986. - 184 с.

18. Тимаков В. Д. Микробиология. - М.: Медицина, 1983. -512 с.

Вісник Дніпропетровського університету. Біологія, екологія.

Vìsnik Dnìpropetrovs'kogo unìversitetu. Serìa Bìologîa, ekologîâ Visnyk of Dnipropetrovsk University. Biology, ecology. Vìsn. Dnìpropetr. Unìv. Ser. Bìol. Ekol. 2007. 15(1).

ISSN 2310-0842 print ISSN 2312-301X online www.ecology.dp.ua 
19. Цавкелова Е. А. Образование ауксинов бактериями, ассоциированными с корнями орхидей / Е. А. Цавкелова, Т. А. Чердынцева, А. И. Нетрусов // Микробиология. - 2005. Т. 74, № 1. - С. 55-62.

20. Чорногор Н. П. Дослідження рістстимулюючих властивостей лізоензимного препарату Streptomyces recifensis variant lyticus. Автореф. дис. ... канд. біол. наук. - К., 1998. - 20 с.

21. Влияние некоторых аминокислот и других соединений на биосинтез тирозина / Б. Р. Штейман, Е. А. Середенко, А. М. Макухина и др. // Проблемы изыскания и биотехнологии новых антибиотиков. - Пущино, 1982. - С. 36-37.

22. Bradford M. M. A rapid and sensitive method for the guantitation of microgram guantities of protein utilizing the principle of protein-dye-binding // Anal. Biochem. - 1976. - Vol. 721. P. 1117-1123.

23. Fallik E. Morphology and physiology of plant roots associated with Azospirillum / E. Fallik, Y. Okon. - London: CRC, 1994. - P. 77-86.

24. Isono M. Bacteriolytic enzyme and process for the production there of. Pat. 3649454 USA, C 12 K 1/06 / M. Isono, T. Takahashi, Y. Yamadzaki. - Pat. 1004.72.

25. Luengo J. M. Lisine regulation of penicillin biosinthesis in low producing and industrial strains of Penicillium chrisogenum / J. M. Luengo, G. Revilla // J. Gen. Microbiol. - 1979. Vol. 115. - P. 207-211.

26. Menta R. Lysine stimulation of cephalosporin C. synthesis in C. aeramonium / R. Mehta, J. L. Speth, C. H. Nach // Eur. J. Appl. Microb. and Biotech. - 1979. - Vol. 8. - P. 177-180.

Надійшла до редколегії 10.11.2006

Вісник Дніпропетровського університету. Біологія, екологія.

Vìsnik Dnìpropetrovs'kogo unìversitetu. Serìa Bìologîa, ekologiâ

Visnyk of Dnipropetrovsk University. Biology, ecology. Vìsn. Dnìpropetr. Unìv. Ser. Bìol. Ekol. 2007. 15(1).

ISSN 2310-0842 print ISSN 2312-301X online www.ecology.dp.ua 